\title{
States and sovereignty in the Middle East: myths and realities
}

To many observers the Middle East states system since the Arab uprisings remains at a critical juncture. The uprisings, which started late in 2010, were revolutionary in their initial impact, but beyond Tunisia, it is the counterrevolutionary movement has proved more durable. ${ }^{1}$ However, the region has witnessed multiple regime changes alongside intense levels of popular mobilisation, violence and transnational activism. The results have been highly destabilising, resulting in challenges to the very sovereignty and territorial integrity of states. This situation, in turn, has contributed to a shifting regional balance of power and repeated episodes of external intervention. Some commentators have argued that the whole regional system, always fragile and contested, is finally undergoing radical transformation; others point to its resilience. This article evaluates the latest wave of instability and its consequences for Middle Eastern states, their sovereignty and regional order, introducing themes and discussions taken up in other articles in this special issue. It argues - connecting directly to the Zartman article - that despite recent upheavals (and multiple predictions to the contrary), it is likely that the Middle East system of states and borders will remain largely intact - at least in the medium term. This does not mean that states are necessarily 'strong' in a Weberian sense or that sovereignty at different levels is uncontested, but that continuity - state (even regime) survival and border preservation - is likely to prevail over major change.

To demonstrate the above, the article evaluates recent events against evolving patterns and conceptions of statehood and sovereignty over time. It argues that understanding the contemporary region requires stepping back from the present and taking a long view of the evolution of states and sovereignty in the modern Middle East. It rejects the use of popular myths and stereotypes, about artificial or failed states or imminent system implosion, and calls for a stocktaking of the state of the Middle East state. In doing so it also considers the Middle East experience comparatively, looking at parallel state trajectories

\footnotetext{
${ }^{1}$ Richard Falk, Rethinking the Arab Spring, Third World Quarterly, 37/12, 2016 2322-2234.
} 
elsewhere. Taking such an historical and comparative perspective permits close analysis of the particular conditions under which modern states were established and helps to track their principal features and development. There are many transformative features, which yield new insights - whether vacuums of state authority, the agency of transnational forces and border porosity - but also continuities in respect to states' legal personalities, institutions and identities, which have survived and developed across time. Highlighting such continuities amid change, the aim of this framing piece is not to offer a fullyfleshed out conceptual framework (see Raffaella Del Sarto's article), but rather to provide some tentative answers to the wider questions addressed in this special issue on contested MENA borders. Namely, how robust is the Middle East states system and its accoutrements of sovereignty, 'Westphalian' or otherwise, a question posed by Middle East scholars long before the Arab uprisings? ${ }^{2}$ Why has it been so often assumed that it is in danger of implosion and are the dangers of implosion greater today than in the past? ${ }^{3}$ And, in answering this question do we need to rethink the general principles of statehood and sovereignty, adopting critical or post-colonial perspectives; or to discard such concepts altogether?

Addressing these questions is important from a number of perspectives. The consequences of the Arab uprisings are of obvious significance, not only to the future of the region and its component states, but also from a wider International Relations (IR) perspective. They impact upon major external actors and institutions in multiple ways, whether the US, Russia, China, the United Nations or European Union, all of whom remain deeply involved in economics, politics and security of the region - indeed whose very actions may yet determine some of the issues at hand. Regional events are also important for testing theoretical perspectives since they challenge us to recalibrate assumptions about political change, state durability and survival in certain settings.

This article calls for caution about claims of state breakdown and alarmist predictions about what ongoing unrest means for regional states, borders and

2 Gregory Gause, 'Sovereignty, Statecraft and Stability in the Middle East ', Journal of International Affairs 54/2 (2002) 411-469 ${ }^{3}$ Mohammed Ayoob, Will the Middle East implode? (Cambridge, Polity, 2014) 
sovereignty. After a brief review of post-Arab uprising events, it offers first a critical perspective of some prevailing assumptions or myths about the current regional disorder and state fragility by placing these in comparative and temporal context; second it considers the wider trajectory of sovereignty and statehood in the modern Middle East, to review longer term patterns and trends and their possible implications; third, it considers whether or not the vocabulary of International Relations and its current focus on a binary divides between strong and weak states or 'good' versus 'bad' governance, is adequate for the task of understanding the present conjuncture; and finally it offers some more general conclusions about the implications of the present state/border contestation and assesses the extent to which recent events should be seen as a turning point or 'critical juncture' in terms of statehood, sovereignty and institutions. In doing so, it draws on both the work of International Relations and Middle Eastern scholars who have contributed to the debate in different ways, whether by applying a wider IR lens or by examining more closely the particularities of the Middle East system, or combining both in an attempt to build disciplinary bridges. ${ }^{4}$ There are two core sovereignty considerations to keep in mind: domestic and international, though the two are obviously interdependent. That the Arab uprisings and their aftermath have generated domestic political changes with long term repercussions cannot be disputed, but how these changes will play out in terms of state authority and institutions remains unclear; whether or not they will result in major international changes including state breakdown and the redrawing of borders is far less certain (as evidenced by the evolution of the Syrian war toward the re-centralisation of Assad's control) and here traditional international relations scholarship has hitherto proved largely correct in predicting state resilience in an anarchical selfhelp system , notwithstanding the multiple and often contradictory impacts of bottom up and top down pressures supplied by social movements and globalization.

\section{The Arab uprisings revisited}

\footnotetext{
${ }^{4}$ See International Relations Theory and the Changing Middle East, POMEPS Studies 16 (2015) http://pomeps.org/wp-content/uploads/2015/09/POMEPS_Studies_16_IR_Web1.pdf
} 
Though the Arab uprisings unleashed what appeared to some as a 'democratizing wave', 5 with no immediate implications for state borders and external sovereignty, time revealed how the initial popular movements, which saw the toppling of a number of leaders, generated processes that transcended simple regime change, while the effects of democratization remain patchy or, in some cases, have reversed. Moreover, what started as a series of domestically driven events have had widespread regional and international repercussions, though their long-term impact on the structure of the regional system remain uncertain. The word revolution was widely used to describe the effects of the early Arab uprisings, but outside Tunisia, the revolutions remain unfinished or have been reversed. ${ }^{6}$ Providing a road map to better understand present events and their possible implications for Middle East states is therefore important for scholars and policy-makers alike.

The 'Arab Spring', a somewhat maligned term with orientalist undertones, which captured the initial dynamic of the movements that swept the Arab world from late 2010 - quickly evolved beyond regime change into a far more complex and multifaceted affair into which multiple players, state and nonstate, regional and extra-regional have been drawn, with the effect that in certain cases, the very states and territories upon which the modern state system has been based for nearly a century have appeared in danger of unravelling. States like Iraq, Libya, Sudan, Syria and Yemen in 2016 occupied positions ranging from 4 to 25 on the Fragile States Index, ${ }^{7}$ (Egypt was 38) reflecting multiple indicators of vulnerability. Some borders in these states today remain highly porous and contested and the locus of state authority is under challenge. All are undergoing processes of political and social reconfiguration whose outcome remains undetermined. New sites of governance have emerged, or been strengthened, as

\footnotetext{
5 Robert Springborg, 'Wither the Arab Spring: 1989 or 1848?' International Spectator, 46: 3, 2011; Larry Diamond, 'A Fourth Wave or a False Start? Democracy after the Arab Spring', Foreign Affairs, May 2011.

${ }^{6}$ Marc Lynch, The Arab Uprising. The Unfinished Revolutions of the New Middle East, (New York: Public Affairs 2012; Falk, 'Rethinking the Arab Spring'.

7'Fragile States Index', Fund for Peace, Washington, 2016. (http://fsi.fundforpeace.org/)
} 
in Iraqi Kurdistan, where the Kurdistan Regional Government (KRG) established under the 2005 constitution, enjoys a considerable degree of autonomy within a nominally federal state, as does Rojava - the de facto autonomous Kurdish region in northern Syria; or in Libya where competing governments have coexisted in the former capital Tripoli and in Tobruk to the east of the country; or in the borderlands of these and other states - the subject of other articles in this special issue - where local groups exercise authority beyond the reach of the central government.

The undermining of centralised authoritarian rule - the mainstay of most Arab regimes - and the subsequent failure to install new more legitimate and inclusive governments, exposed the systemic fragility of the state-society contract leading, in some cases, to anarchy or the return to a kind of pre-state model, with authority divided between different regional; ethnic; tribal and religious groups, some aided by external powers. There are parallels with the more decentralised structures of authority in the former Ottoman Empire, but a key difference is the fragmentation of governance, comprising the absence of any overarching power structure within (in some cases) or between states. One contemporary example of this is the lack of any effective regional organization that might have mitigated the effects of regional unrest: there is no Middle Eastern 'union'. A related feature is the absence of strong leadership, whether from inside or outside the region. ${ }^{8}$ Just as there is no relevant regional organization to help restore a regional equilibrium, there is no established regional hegemon playing the role that Egypt attempted, say, in the 1950s and 1960s. A number of states today compete for this position -Saudi Arabia, Iran, and Turkey, with Israel as an outlier great power - but they are divided amongst themselves, forming different regional axes. Nor is there a single dominant external power holding the regional balance - no 'pax-Americana' - but a weaker US (and European) presence and, a relatively strong and competitive Russian one. This absence of external leadership is exemplified by the outcome of the Iraq War, which exposed the poor planning and failed administrative

\footnotetext{
${ }^{8}$ Louise Fawcett, 'Regional leadership? Understanding power and transformation in the Middle East' in Regional Powers and Regional Orders, Nadine Godehardt and Dirk Nabers eds. (London: Routledge 2011) 155-172.
} 
reform of the Iraqi state, as revealed in the long awaited UK-commissioned Chilcot enquiry, published in $2016 .{ }^{9}$ It is an outcome that, both positively and negatively, has deterred and complicated further regional involvement by Western powers, but also left space for Russian engagement in its near abroad. Considered together, this crisis of regional governance and absence of leadership help explain the current disorder. Whether this state of affairs is merely temporary or will result in more permanent changes to state authority and borders remains unclear as the different contributions to this journal issue show.

If local governance appears weak, there are important distinctions between states. Some have appeared in more serious danger of unravelling; others by contrast seem stronger. Arab monarchies have been more robust than their republican counterparts (a process already underway but particularly visible after the Iraq War of 2003), suggesting that monarchies have been better at garnering legitimacy and centralizing power. ${ }^{10}$ Access to oil rents and enhanced welfare provision (with the exception of Libya) have been decisive in offsetting instability, ${ }^{11}$ though no Gulf state is immune from unrest, as the Bahrain case revealed. One result of these changes in state capacity is the way in which the regional balance of power has shifted, giving greater agency to states like Saudi Arabia and the smaller Gulf monarchies on the one hand, and Iran and Turkey on the other. Iran, which experienced revolution in 1979, and widespread popular protest in the 'Green Movement' of 2009, has been less directly affected by regional instability than its Arab neighbours and has repositioned itself in the wake of the Iraqi and Syrian crises, consolidating regional alliances, actively supporting the Houthis in Yemen's civil conflict and Assad in Syria. Iran's international position furthermore, stabilised somewhat after the 2015 Joint Comprehensive Plan of Action to restrict its nuclear programme, though its relationship with outside powers remains volatile in the light of events in Syria and following the US elections where President Trump has implied a tougher US line on Iran. Saudi Arabia and Iran, furthermore,

\footnotetext{
${ }^{9} \mathrm{http}: / /$ www.iraqinquiry.org.uk/

10 Lisa Anderson, 'Absolutism and the Resilience of Monarchy in the Middle East', Political Science Quarterly 106:1, 1991, 1-15.

11 Rolf Schwarz, 'Does war make states? Rentierism and the formation of states in the Middle East', European Political Science Review 3/3, 2011: 419-443.
} 
remain fierce competitors, (visible in the ongoing Yemen conflict) and their competition increases regional volatility. In the emerging order, much will depend upon the roles played by such major powers and their international alignments: not only Iran and Saudi Arabia, but also Israel and Turkey (notwithstanding the latter's internal challenges). In respect of these alignments, Russia, a longstanding Syrian partner, has been closely involved in different stages of the Syrian conflict and remains a key player there. The US, in turn, has been a leading negotiator in the deal over Iran's nuclear programme and though the future direction of US foreign policy remains uncertain, it will likely be party to whatever settlement eventually emerges in Syria.

Alongside such shifts and rebalancing, the evident instability has generated enormous speculation about the viability of the regional system of states, and to prognostications of its major reconfiguration or even demise. Such speculation is not new, as discussed below, but arguably reached new heights in the years immediately after the early Arab uprisings. An exercise in Googling the catch phrase 'the end of Sykes-Picot', in reference to infamous secret agreement between Britain and France in 1916 to divide up the postOttoman region, yields a bombardment of search results (over 350,000 in mid2015) from a variety of sources including journalists, Western diplomats and Da'esh propagandists. ${ }^{12}$ Judging from the media and some academic coverage, many agree with the claim that 'Sykes-Picot', a metaphor for the contemporary states system, is dying or already dead.

A few examples illustrate the point. In 2015 an International NYT article proclaimed: 'The old Middle East order is in tatters. Post-Ottoman states that were not nations, with century-old borders drawn up by Europeans, have split along sectarian lines and made nonsense of these borders'. ${ }^{13}$ A year later the New Yorker ran an article: 'How the Curse of Sykes-Picot still haunts the Middle East'. Conveying a similar message, Maddy-Weitzman has written of the Arab states reaching a 'Shakespearean moment: "to be or not to be".'14

12 Cf Gregory Gause, 'Is this the End of Sykes Picot?' Washington Post, May 20 2014.

13 Roger Cohen, International NYT, 28 August 2015.

${ }^{14}$ Bruce Maddy-Weitzman, A Century of Arab Politics (London, Rowman and Littlefield, 2016) 213. 
The above views have been widely shared and reproduced, particularly by those who have an interest in, and possibly something to gain from state fragility in the Arab world - and this applies to both regional actors and external powers alike. If the Arab state system is failing, this may legitimise claims by nationalist groups like the Kurds of Iraq or Syria, or other non-state actors (like Da'esh), or facilitate intervention by regional actors, (as in the case of the Saudis and Iranians in Yemen), or indeed external powers as occurred in Libya, and also in Syria. Intervention in these cases is about 'saving' failing states. Hence we should ask who calls states 'failed' and why.

\section{Rethinking fragile and artificial states}

How robust are assumptions about state fragility and a fractured regional order? Claims about state weakness, or state breakdown, as currently applied to parts of the Middle East, are not new. They have been repeated since the emergence of the state system after the First World War, and therefore any new attempt to revive them after 100 years should met with some scepticism. There would need to be compelling evidence to validate the view that states in the Middle East were indeed fracturing. However, a more plausible claim that distinguishes a de jure state from a de facto state could be made, particularly in the light of the generalised fragmentation of authority and border contestation that is the subject of this issue. In other words, the 'state shell' or territorial unit may survive in a formal legal sense, while the integrity of borders, alongside sources of internal authority become contested or fragmented. In some states this situation has clearly prevailed- Iraq, Libya, Syria - though it is too early to judge whether the breakdown of authority will be temporary or more prolonged, as the Iraqi and Libyan cases suggest. However, state shells are important for defining the legal parameters and personalities of states, even if those parameters are temporarily suspended in times of conflict. They are therefore an important aspect of sovereignty. Before pursuing this point further, or drawing any conclusions about regional order today, it is therefore worth thinking further about what state failure really means and where state failure has been observed, and with which consequences, in the recent past. 
Beyond instances of major war or imperial breakdown, complete state failure has been often predicted over the past century, but has rarely occurred or endured: state survival rates are high. In this respect it is perhaps surprising, in discussing the Middle East, that little reference has been made to other recent cases of so-called state failure and their outcomes. In 2002 Robert Rotberg wrote: 'Although the phenomenon of state failure is not new, it has become much more relevant and worrying than ever before. In less interconnected eras, state weakness could be isolated and kept distant. Failure had fewer implications for peace and security. Now these states pose dangers not only to themselves and their neighbors, but also to peoples around the globe. Preventing states from failing, and resuscitating those that fail, are thus strategic and moral imperatives.' 15

How easily could this have been written about the contemporary Middle East? Rotberg was referring to the international security implications of failed states, particularly African states, in the post-Cold War era. But the views expressed help understanding of what is meant by state failure and how to apply the term. A key feature is the incapability to project state power; to assert authority within borders (a central attribute of sovereignty), leaving the territory 'governmentally empty', hence only the state 'shell' remains. ${ }^{16}$ Excluding South Sudan, a new state in conflict on the borders of the region, this could apply to a greater or lesser degree to at least four states: Yemen, Syria, Iraq and Libya. If not governmentally empty, they reveal a number of common features including civil conflict, border porosity, and fragmentation of governance. Going on to describe some of the features that mark the road to state breakdown and failure, however, Rotberg also advises that failed states are not homogeneous, arguing that geography, history and politics all affect weakness and vulnerability. ${ }^{17}$ This point is of particular importance in relation to Arab states whose make-up is diverse and defies generalisation. Individual agency also matters: whether in the Middle East or Africa the actions of individuals and their supporting military elites (whether Hussein, Gadhafi, Asad,

15 Robert Rotberg, 'Failed States in a World of Terror', Foreign Affairs, July/August, 2002: 127.

16 Ibid: 128.

17Ibid: $127-28$. 
Mubarak) have been critical in determining outcomes. So, of course, have the opposing/supporting roles of outside powers.

This is not the place to elaborate upon state failure in International Relations, but to underline the point that before drawing new conclusions about states, their territorial integrity, sovereignty deficits and governance failures in the Middle East we should select terms carefully. A concept used indiscriminately is both deficient and counter-productive. ${ }^{18}$ As scholars of developing countries frequently remind us, we should beware the pitfalls of generalizing theory and its crude application to any given regional environment. ${ }^{19}$ Calling states failed could be self-fulfilling if the definitions favour the strong and disempower the weak state. States like Venezuela today are labelled 'failing', perhaps to justify the view that intervention by the international community to fix its sovereignty deficits might, at some point, become justified.

It is also worth emphasising that state fragility and breakdown are neither inevitable nor necessarily permanent; in fact they are frequently arrested, or reversed. Territorial redrawing - a possible outcome of state breakdown - is the exception rather than the rule worldwide and has tended to follow major wars or imperial collapse (the First and Second World Wars; the break up European empires and of the USSR) and often requires the endorsement of major powers and international institutions (as in the former Yugoslavia). Just as states may reach breakdown, they also may be restored to different degrees of health, by international or regional organizations, or by a hegemonic power. ${ }^{20}$ Despite multiple predictions of the demise of a number of African states after the Cold War, ${ }^{21}$ existing boundaries were largely maintained. Hence, the supposed critical juncture provided by the end of the Cold War did not produce major boundary changes in Africa without the consent of concerned

18 Charles Call, 'Beyond the Failed State. Towards conceptual alternatives'. European Journal of International Relations, 17/2 (2011) 303-26

${ }_{19}$ Pinar Bilgin and Adam Morton, 'Historicising representations of failed states: Beyond the Cold War annexation of the Social Sciences'. Third World Quarterly, 23/1 (2002) 55-80

${ }^{20}$ Rotberg, 'Failed States': 134-35.

21 Jeffrey Herbst, 'Challenges to Africa's borders in the new world order', Journal of International Affairs, 46: 1 (1992): 17-30 
parties. $^{22}$ With the possible exception of the Kurdish areas of north/northeastern Iraq and Syria the same may hold true of the contemporary Middle East.

Just as the discussion of state failure is not new, nor is the argument that the Middle East system itself is endangered. First, as noted, the claim about the potential unravelling of the post-war system or 'the end of Sykes-Picot' in reference to the informal Anglo-French agreement sketched out during WW1 regarding the future of the Ottoman territories has been repeatedly made and it is important to place this debate in context. Scholars and media pundits have regularly predicted and speculated about its demise. The same holds true for other regions, like Africa and South Asia, where borders have been imposed by former colonial powers, even where such imposed borders have become robust. This speculation is unsurprising given the nature of its construction and its frequently discussed and much-publicized artificiality. Indeed the narrative of state artificiality in Middle East constitutes a well-established myth. David Fromkin wrote of the period 1914-1922 as one in which Middle East countries and frontiers were fabricated in Europe'. ${ }^{23}$ Since that era, the term 'artificial' has been repeatedly used whether to explain the sources of regional instability: the consolidation of authoritarianism, the rise of sectarianism or the intractability of conflict. Long before the Arab uprisings, the region was regularly buffeted by internal and external challenges - wars, civil and inter-state, and multiple interventions - many of which appeared to pose challenges to the sovereignty and territorial integrity of states. Important moments have been the creation of Soviet-backed regimes in northern Iran in 1945 which raised the early possibility of a Kurdish republic and even a union between the two Azerbaijans; ${ }^{24}$ the different Arab-Israel conflicts starting with the war of 1948 (here the issue of contested territory and sovereignty over what was the Palestinian mandate, now mostly Israel, is still on-going); Morocco's annexation

\footnotetext{
${ }^{22}$ Lee Seymour, 'Sovereignty, territory and authority: boundary maintenance in Contemporary Africa', Critical African Studies, 51: 1 (2013): 17-31.

${ }^{23}$ David Fromkin, A Peace to End All Peace? The Fall of the Ottoman Empire and the Creation of the Modern Middle East. (New York: Avon Books, 2009). ${ }^{24}$ Louise Fawcett, Iran and the Cold War, (Cambridge, Cambridge University Press, 2009)
} 
of the Western Sahara; the Iranian Revolution, the Iran-Iraq War, the wars in Lebanon and the Gulf, all of which raised the prospects of possible fragmentation and border redrawing (had Kuwait been effectively annexed by Iraq for example). So, in a different way, did the short-lived United Arab Republic (1958-1961) which briefly exposed the possibility of a greater Arab state. Therefore, the claim of artificiality, the challenge to existing borders by outsiders and insiders - state and non-state - and the prospect of territorial revision and new sovereign entities, have many pre-2011 precedents. Interestingly, none of the above events produced permanent fragmentation, or major border redrawing, though some conflicts remain inconclusive. This, at first sight, supports the claim that the Arab state, albeit 'alien and besieged' is nonetheless 'here to stay'. 25

Two further points suggest themselves: artificiality is a lazy shorthand which avoids the need for unpacking a complex, contested but hitherto quite durable state system; second, it is a relative concept judged against an almost unrealizable ideal type of sovereign state - part of a 'Westphalian myth' - which has little resonance outside particular geographic and temporal settings. ${ }^{26} \mathrm{Few}$, if any states around the world conform fully to the Westphalian ideal, and even the archetypal artificial state, Iraq, with its ethnic and religious division, has displayed coherent nationalist features. ${ }^{27}$ Most citizens of the Middle East today identify with 'their' state alongside other tribal, religious or ethnic associations.

\section{The end of Sykes-Picot?}

Another lazy and related shorthand now with quasi-mythical status is the overused and inaccurate claim about the 'end' of Sykes-Picot. To understand the contemporary borders and their history we need to consider not only the SykesPicot agreement of 1916, but also the earlier McMahon-Husayn correspondence (1915) and the Balfour Declaration (1917) - alongside other agreements entered

${ }^{25}$ Bahgat Korany, 1987, 'Alien and Besieged yet Here to Stay? The Contradictions of The Arab State', in Giacomo Luciani (ed), The Foundations of The Arab State (Abingdon, Routledge, 1987) ${ }^{26}$ Andreas Osiander, 'Sovereignty, International Relations and the Westphalian Myth', International Organization 55: 2, 2001: 251-87.

27 Fanar Haddad, Sectarianism in Iraq: Antagonistic Visions of Unity (London: Hurst and Co., 2011) 
into by Britain, France and Russia and Arab leaders and Zionists during WW1 and finally and importantly the San Remo Treaty (1920). ${ }^{28}$ It was the latter, not Sykes-Picot, which outlined the details of the borders and system of mandates to be imposed on the region. For example, San Remo overturned French hopes in respect of the Iraq-Syria border and control of Palestine, reflecting Britain's predominant position after the war. It reflected also the influence of US President Wilson on the Versailles settlement with the mandate system implying accountability to the League of Nations and including a provision for eventual independence. ${ }^{29}$ As Gause has pointed out we should be referring to the 'end' of San Remo' rather than Sykes-Picot. ${ }^{30}$ It is important to note also that the agreement was never about a new system of borders for the whole region but one that was restricted to ex-Ottoman lands in the Fertile Crescent, territory which became Iraq, Syria, Lebanon, Jordan and Palestine/Israel. Turkey's borders were regulated by the separate agreements at Sevres then Lausanne in 1923. However, to a degree Sykes-Picot represented the sentiments of colonial powers and it is valid to claim, that regardless of the territorial limits of San Remo itself, most states of the region - whether mandates or not - were subject to extraordinarily high levels of external penetration and influence with longstanding consequences for their sovereignty and regional stability. The former was often conditional. Iran is an obvious example: never a formal colony, but an independent state where there were huge levels of external involvement. Britain, for example, both helped to engineer the installation (in 1921) then the removal (in 1941) of Reza (Khan) Shah before occupying parts of the country as part of the war effort. It then co-orchestrated with the US the coup against the nationalist Prime Minister Mossadeq in 1953 in favour of the Shah's son Mohammed Reza. Despite this assault on Iran's sovereignty and scattered nationalist uprisings, Iran's borders have since remained stable, even at times of revolutionary upheaval and war.

\footnotetext{
${ }^{28}$ Eugene Rogan, The Fall of the Ottomans (London Penguin, 2015) 390-95

${ }^{29}$ Peter Sluglett, 'An Improvement on Colonialism? The 'A' Mandates and the Legacy in the Middle East', International Affairs, 90/2, 2014.

${ }^{30}$ F Gregory Gause, 'Is this the End of Sykes Picot?' Washington Post, May 20 2014.
} 
The prevalence of external influence in the region does not fully support claims about state or system fragility. Jordan, one of the most 'artificial' yet ultimately successful mandates, ${ }^{31}$ is not about to disappear; nor is Israel. Lebanon does not fully control all of its territory or borders; there are multiple competing groups and sites of authority, but the Lebanese state remains, because powerful domestic (and external) actors wish it. The borders of Syria, Iraq and the Egyptian Sinai remain highly volatile and contested (as discussed elsewhere in this issue); yet the territorial gains of Da'esh, against dire predictions, have receded since 2015; parts of once porous Syrian-Turkish border have hardened (see Okyay article). In short, despite long-standing and region-wide claims of imposition and artificiality, amid ongoing challenges, most of the borders have survived.

Writing shortly before the Arab uprisings, Fred Halliday observed how 'in contrast to other regions of the world marked by interstate conflict and nationalist upsurge, for example in formerly communist Europe, the Horn of Africa, and South Asia, the map of states characterizing the Middle East, and indeed the Arab world as a whole, has remained constant. For all the talk of state unification and/or fragmentation, of the artificiality of borders, and of the vagueness of 'Arab' identities, whether pan-Arab or state specific, this map of the region, forged by colonialism and war in the early part of the twentieth century, has endured.' 32

Halliday's untimely death in 2010 prevented him from reviewing these conclusions. One wonders however, whether they would have been significantly altered by the subsequent course of events. Though states have been seriously weakened by internal and transnational challenges, which in turn have been abetted by outside influences; though previously centralized governments cannot, for now, fully control their states and borders, giving rise to new or contested centres of authority, the evidence so far suggest that states, in most cases, will likely survive. And here the African case described above presents as

\footnotetext{
${ }^{31}$ Yoav Alon, The Making of Jordan: Tribes, Colonialism and the Modern State (London: I.B. Tauris, 2007)

32 Fred Halliday (2013), 'Nationalism in the Arab World since 1945', Oxford Handbook of the history of Nationalism, (Oxford, Oxford University Press) 436.
} 
a useful comparator, where state fragility and weakness has not resulted in significant boundary change even in the volatile Horn of Africa. ${ }^{33}$

\section{Quasi states}

Talk of fragile and artificial states recalls descriptions of the post-colonial 'quasi' state. ${ }^{34}$ In such states, the legal façade of sovereignty, of formal independence, persists and is actively promoted by the international community and local elites, while other recognisable attributes of sovereignty: popular legitimacy and effective institutions, alongside territorial integrity and respect for the principle of non-intervention, are weak or non-existent, giving rise to the claims of fictional sovereignty or quasi-state status. The quasi-state idea is reinforced by Krasner's descriptions of the 'hypocrisy' of sovereignty in multiple settings. ${ }^{35}$ There is no doubt that this limited or partial sovereignty has, to a greater or lesser degree, been visible over the last century and is dramatically evidenced in a state like Libya where following civil war and intervention, sovereignty at all levels has been eroded and alternative sites of power compete; Yemen, a previously divided state, also in the throes of a destructive civil war, is similarly challenged. Still, we should remain wary of overusing the term quasi-state for the old Third World or today's Global South - value-laden terms in themselves even if it is a condition reflected in parts of the Middle East at the present juncture. 'Quasi-state' like failed state is another inherently subjective term against which 'mature' or 'successful' statehood or 'full' sovereignty - all ideal types - are measured. Post-colonial states, even where independence was acquired two centuries ago, as in the Latin American cases, are still rarely dignified in International Relations scholarship with the attributes of full sovereignty - an award almost exclusively accorded to the non-colonised advanced industrialised and mostly Western world.

In respect of the modern Middle East, despite border porosity (as mirrored in the African cases) and the breakdown of centralized authority,

\footnotetext{
33 Seymour, 'Sovereignty, territory and authority'.

34 Robert Jackson, Quasi States. Sovereignty, International Relations and the Third World, (Cambridge, Cambridge University Press, 1993).

35 Stephen Krasner, Sovereignty: Organized Hypocrisy (Princeton, Princeton University Press, 1999)
} 
sovereignty, with its multiple and evolving faces, remains an important common anchor. The majority of domestic and indeed many external actors desire continuity over change in terms the integrity of borders, even if the locus and nature of state authority is contested. Indeed scholars note how widespread sectarianism, rather than providing evidence of imminent state breakdown, has been used instrumentally to securitize regimes. ${ }^{36}$ In short, despite the historic and contemporary pull of supranational and transnational forces that have long coexisted in the region, the tendency towards state consolidation rather than fragmentation has prevailed. This is most dramatically witnessed in Syria, where, in 2017, following high and continuing levels of violence, the reassertion of Assad's authority continues. This reflects not only the desire of local states and actors with an interest in the regime's survival (Iran, Iraq, Hezbollah) and their external supporter (Russia) but also supports the default position in International Relations, which is favourable to the preservation of the territorial status quo. Again, a comparison with the African case is helpful: the regional architecture has demonstrated a 'strong bias' against boundary change and incumbent elites have worked hard to preserve existing state boundaries. ${ }^{37}$ In the international system the major unit of currency today - and passport to participation in that system and its institutions - is (with few partial exceptions) still states. There is no doubt that this interpretation is open to challenge; that the 'territorial entrapment' of states may prove ephemeral, ${ }^{38}$ and that the hierarchy currently enjoyed by states could shift, but its resilience and explanatory power is still strong. And it is no less strong among so-called weak states. Indeed, weaker states are particularly attracted to the protection and legitimacy that formal sovereignty provides. ${ }^{39}$

The above discussion highlights why, before drawing premature conclusions about the present juncture and its possible outcomes for domestic, regional and international politics; and before providing policy prescriptions, it

36 Elizabeth Monier, Regional Insecurity after the Arab Uprisings, (London, Palgrave, 2015).

${ }_{37}$ Jeffrey Herbst, States and Power in Africa. Comparative Lessons in Authority and Control (Princeton, Princeton University Press 2014) xv-xvi.

38 John Agnew, 'The Territorial Trap: The Geographical assumptions of IR theory', Review of International Political Economy 1/1: 53-80 (1994) 39 Joel Migdal, Strong Societies, Weak States, (Princeton, 1988). 
is important to think comparatively and reflect on other parallel cases, but also to think historically, and with a critical conceptual eye, by looking at how statehood and sovereignty have travelled over time as highlighted in the following section.

\section{Revisiting history and concepts}

Thinking historically means that we do need to return, at least metaphorically, to Sykes-Picot, or even earlier, to better understand the present. This section both explores relevant concepts and their applicability and offer further context to understanding and analysing the current situation. Constructing a bridge between the past and the present underlines Roger Owen's point about paying serious attention to the regional history of the Arab world and exploring those conditions - external and internal - which gave rise to the types of states, and the regimes that have nurtured these states, some of which today appear under challenge. ${ }^{40}$ This point is one that area studies scholars rightly insist upon, critiquing social science methods that neglect regional particularity and detail. ${ }^{41}$ Failing to understand such conditions leads to wrong conclusions, or the use of lazy shorthands noted above. Alongside this and closely related to the historical context, this section will also reconsider how the very concepts of statehood and sovereignty were received and have travelled from the late Ottoman period to the present and with which consequences for regional and international order. This will help to critically re-evaluate the conditions under which state persistence was made possible and also to contextualise the current demands for change.

At one level, examining the concepts of sovereignty and statehood and pursuing their Middle Eastern trajectories has precisely given rise to arguments that reinforce the failing state idea, by showing how these very concepts had always been thinly embedded or non-existent in the region. The same case has been made for democratization. If such concepts did not take root, or were only

40 Roger Owen, The Rise and Fall of Arab Presidents for Life, (Cambridge, Cambridge University Press 2012).

${ }^{41}$ Morten Valbjorn, 'Towards a Mesopotamian turn: Disciplinarity and the Study of the International Relations of the Middle East', Mediterranean Studies 14/1-2 (2004) 47-75. 
rooted superficially by external powers, elites or authoritarian veneer, the disruptions caused by Arab Spring become comprehensible in terms of a final unravelling of an already fragile, imposed and thereby illegitimate system, revealing these concepts as alien and empty of meaning. This then leads into a discussion of exceptionalism, a terrain frequented by scholars of the Middle East, and revolving around whether or not states and the accoutrements of sovereignty are the right frames and concepts to apply to regions like the Middle East. Such a view is attractive to those who regard the Middle East as lost in a world of illiberalism and 'oriental despotism' 42 and therefore incapable of taking on the features of modern statehood. Scholars of Islamic history and governance, from a different perspective, also point to the inappropriateness of such formulas drawing on unitary Islamic doctrines - as discussed in the article by Adraoui.

A more nuanced line of argument that critical and post-colonial theorists have advanced not only for Middle East but other parts of the developing world, questions both the hierarchy and the suitability of Western-designed concepts for other world regions. Because of inbuilt temporal, geographical and ideological biases they are both blind to local conditions and lacking in universal applicability. ${ }^{43}$ As such they are not necessarily the appropriate frames for viewing distinct regions or for constructing a universal narrative of statehood. There is a melange of helpful contributions here from Amitav Acharya's discussion regarding the localization of international norms, to Pinar Bilgin's critique of accepting dominant Middle East definitions and advocacy of alternative lenses of which Arabism and Islam are two examples. ${ }^{44}$ Rejecting the automaticity and privileging of particular state and sovereign outcomes is reflected also in the wider theoretical arguments of Sanjay Seth and Dipesh Chakrabarty 45 - in which Europe is 'provincialized' - put back in its historical

\footnotetext{
42 Kedourie, 1992: 12, 14; Bernard Lewis, What Went Wrong? Western Impact and Middle Eastern Responses, London: Pheonix Publishers, 2002) ${ }^{43}$ Andrea Teti, 'Bridging the Gap: IR, Middle East Studies, and the Disciplinary Politics of the Area Studies Controversy', EJIR 13/1 (2007): 117-45.

${ }^{44}$ Amitav Acharya (2014), The End of American World Order (Cambridge: Polity, 2014); Pinar Bilgin, (2004), 'Whose Middle East?', International Relations.

45 Sanjay Seth, 'Historical Sociology and Post-colonial Theory: Two Strategies for Overcoming Eurocentrism', Journal of Political Sociology, 3/3 (2009): 334-338;
} 
and geographical box - rather than placed at the centre of analysis. In these works we are reminded that we cannot simply take concepts for granted, but seek to refine them or employ alternative perspectives or apply local lenses and insights.

The challenge posed by such a diverse group of scholars needs to be taken seriously, not least because, as Ruggie claims, the idea of the territorial state and the accompanying accoutrements of sovereignty are neither universal nor immutable. ${ }^{46}$ Many articles in this special issue address, in different ways, his call to 'unbundle' modern territoriality. However, the non-inevitability of territorial states over the longue durée does not validate a claim to Middle Eastern singularity, unless that claim might be that the region itself will lead the march away from the territorial state. The march away from statehood has been much anticipated in a globalized world, but not yet occurred, suggesting the Middle East, like other regions will retain its state-like character. Even IS, at its height, assumed state-like features . There is, at present, no plausible regional alternative beyond some form of temporary trusteeship or a reconstruction of the existing system. An attempt at remaking or reimagining concepts from a Middle Eastern perspective is not therefore equivalent to a claim that statehood and sovereignty are impossible goals for Middle Eastern states, or that the predominance of states is giving way to the predominance of supra-state or substate actors, since this is plainly not the case in the Middle East or anywhere else. The Middle East is not unique, except perhaps in the Tolstoian sense of the uniqueness of each unhappy family. This assumption of uniqueness recalls a related claim that the Middle East in general and Islamic thought in particular is inherently hostile to ideas of democratic governance. ${ }^{47}$ To present it as such reveals a kind of new, sometimes self-imposed, orientalism; as unhelpful as old externally projected orientalist stereotypes. There is no fundamental incompatibility between the institutions of modern international society and Middle East peoples and states: how could there be since any truly international

Dipesh Chakrabarty, Provincializing Europe: Post-Colonial thought and Historical Difference (Princeton, Princeton University Press, 2007).

46 John Ruggie, 'Territoriality and Beyond. Problematising Modernity in International Relations', International Organization 47: 1, 1993, 139-74

47 Asef Bayat, Post-Islamism (Oxford, Oxford University Press, 2013). 
society is of necessity a collective construction and Middle Eastern peoples and states are an integral part of it? Rather, it all depends on definition, the mix and interpretation.

What is true is that the entry of Middle East states to an international society as mostly defined and designed by the dominant Western powers and their allies was inauspicious to early state building and that this hampered the creation of strong modern states and political systems based upon popular legitimacy. ${ }^{48}$ It is also true that where states were unable to overcome a series of long-term internal and external challenges to their legitimacy, some have faltered, with consequences that we are witnessing today. Yet, the prominent pattern remains state (and border) survival; so before rejecting dominant concepts out of hand, or predicting long overdue regional implosion, it is important rather to understand how these concepts have been applied and received.

\section{Sovereignty's diverse pathways}

How did sovereignty travel since the series of agreements signed during and after WW1 and with which effects for regional and international order? In critically examining the trajectory and different meanings of sovereignty and statehood in MENA - it is helpful to disaggregate sovereignty into its distinctive but related component features: international legal sovereignty, Westphalian sovereignty, domestic sovereignty and interdependence sovereignty. ${ }^{49}$ Tracing these different aspects of 'Sovereignty after Empire' is particularly instructive when considering the contemporary Middle East. 50

In the Middle East many new states that emerged were evidently the triumph of imperial preference over indigenous forces. And each imperial past influenced sovereignty outcomes and choices both negatively and positively, drawing on the effects of both formal and informal empire in the Middle East

\footnotetext{
48 See generally Barry Buzan and Anna Gonzalez Pelaez, International Society and the Middle East, (London: Palgrave 2009.)

${ }^{49}$ Stephen Krasner, Sovereignty, (Princeton, Princeton University Press, 1991): 34.

50 See Sally Cummings and Ray Hinnebusch (eds), Sovereignty after Empire. (Edinburgh University Press 2011).
} 
whether under the Ottomans or then under European colonial rule. Following high levels of colonial control and interference, including attempts at constitutionalism, which persisted beyond empire, a number of these states, notably the Arab Republics, were subsequently captured by authoritarian regimes which consolidated themselves partly thanks to oil and security rents during the Cold War and after. While sovereignty as independence was highly valued and protected by the international environment, as in the quasi-state model above, state and nation-building projects were only superficially addressed as authoritarians enriched themselves and designed ever more sophisticated security structures often aided and abetted by outside powers. The latter meanwhile took lightly the restrictions of non-interference as the cases of Iran, Egypt, and later Iraq showed. ${ }^{51}$ Domestically, co-option and coercion in complex multi-ethnic and religious societies were the tools of choice; liberalizing measures tended only to produce 'democratic facades'. Yet, despite multiple challenges, and cases of 'problematic sovereignty', notably that of Palestine, ${ }^{52}$ these states mostly survived, weathering challenges posed by Arabism and Islam well both beyond the Cold War, relatively unaffected by the changes that swept the former USSR and Eastern bloc (Yemeni unification in 1992 is the exception). They were successful at adapting and mixing different interpretations of sovereignty to their own purposes under the kind of authoritarian conditions advanced by Eva Bellin as reflected in the longevity of many incumbent regimes. ${ }^{53}$ The conditions for state and regime survival provided a cogent justification for the claim that statehood and sovereignty were indeed regionally embedded in the sense of states appearing 'strong', mostly able to defend their borders and ward off internal dissent. ${ }^{54}$ However, other underlying features revealed weak states; the absence of domestic legitimacy; vulnerability to external challenges and internal fracture and it is these features

\footnotetext{
${ }^{51}$ Louise Fawcett, 'The Middle East after Empire: Sovereignty and Institutions', in ibid.

52 Shibley Telhami, 'The Road to Palestinian Sovereignty' in Stephen Krasner ed. Problematic Sovereignty, (New York, Colombia University Press, 2001): 301-322. 53 Eva Bellin (2004), 'The Robustness of Authoritarianism in the Middle East', Comparative Politics 36: 2 2004, 139-157. ${ }^{54}$ Joel Migdal, Strong Societies and Weak States: State-Society Relations and State Capabilities in the Third World. (Princeton, Princeton University Press, 1988).
} 
that in a $21^{\text {st }}$ century international environment provided the foundation stones for subsequent challenges.

Such was the backdrop to the Iraq War and Arab uprisings, both of which, in different ways, have led to a protracted process of contestation and at least the partial unravelling of the authoritarian contract on which prior sovereignty was based. Iraq was a strong or 'fierce' state aspiring to regional hegemony before this challenge was thwarted by external intervention. However, the larger challenges to Iraq's legitimacy and its domestic sovereignty dilemma would have remained an issue regardless of 2003. The Iraq War, in turn, helped to precipitate the Arab uprisings, furthering sectarian divides in a volatile regional system, thereby exposing the vulnerability of incumbent regimes and unleashing region-wide popular movements in an era of easy communications. In the face of economic deprivation, inequality and growing regime corruption, people power - expressed locally and regionally - could make a difference. While people power in the first instance was about peaceful protest and better government, its effects have produced region-wide divides, where regimes and opponents alike have mobilised supporters leading to spirals of conflict and resistance. Hence, though not for the first time since its creation, the Middle East system is in a state of flux and transition. It remains a dangerous and uncertain period, mostly for the peoples of the Middle East themselves, however predictions of major or definitive transformation should be treated cautiously.

\section{Conclusion}

This article has addressed questions surrounding the viability of states, borders and the practices of sovereignty in the Middle East. Undoubtedly, the current environment presents enormous challenges to Middle East states and their sovereignty at various levels and these, in turn, have impacted upon regional and international order. Some authoritarian regimes have fallen; others have been reinstated; some states are still in civil war; still others have have emerged stronger and are likely to uphold a new balance of power. However, with the benefit of six years' hindsight, this does not herald system revolution, or major border or territorial changes. Claims about the 'end of Sykes-Picot' or 
predictions of the 'end for Iraq and Syria' proved premature. ${ }^{55}$ While commentators initially likened the Syrian and Iraqi cases to those of the former Yugoslavia - both were post-WW1 creations with complex political backgrounds and a multi-religious and ethnic mix - their pathways have been quite different.

Not all multi-ethnic, tribal or religious states are designed to fail; many have survived in adverse conditions (already noted are the African cases). Yemen and Libya present more extreme cases of potential fragmentation but with different histories, strategic relevance and as yet uncertain outcomes. Neither were-part of the 'Sykes-Picot' deal and Yemen's problems long preceded the Arab uprisings. But such examples do serve to illustrate the wider point that to better understand the present and to prepare for the future we need to closely examine the current regional context and its history.

What is plain is that a stocktaking of the language, history and faces of sovereignty is needed before reaching premature conclusions about state or system reconfiguration and border redrawing in the Middle East. As suggested, a combination of factors accounts for the present regional situation. These include high levels of popular unrest and social mobilisation which intensified when initial demands were unsatisfied; the relative inability or unwillingness of authoritarians either to retain, or to peacefully surrender power; and the position taken by external powers in alternatively propping up or undermining these regimes. This resulted in an unravelling of the authoritarian contract and the parallel lessening, if not full removal, of great power 'overlay', a term first used by Barry Buzan to describe how 'one or more external powers move directly into the local complex with the effect of suppressing the indigenous security dynamic'. 56 While in the Cold War and its immediate aftermath, the capability of regimes and the appetite for intervention was greater, the post-Iraq War vulnerable and information-rich regional environment was no longer one where authoritarians could so easily hide, or where either the US or its European allies were minded to provide unconditional support either to incumbents, or to regime opponents whose provenance they do not fully support or understand.

\footnotetext{
55 https://www.chathamhouse.org/expert/comment/16104

56 Barry Buzan, People States and Fear. An Agenda for International Security Studies, (London. Harvester Wheatsheaf, 1991)
} 
There were exceptions, the Libyan intervention is one, but that example, like the Iraq War, has reduced the appetite for further intervention.

In the current regional disorder, one that has persisted since 2011, critiques of the Middle East system have proliferated such that 're-imaging the regional map is something a pastime', 57 and Sykes-Picot, a shorthand for imperialism, has become a easy metaphor for all that is wrong with the Middle East system, and an easy target for extremists and would be interveners. Given the amount of attention paid to the post-WW1 agreements and their presumed legacy of weak, illegitimate and failing states, state survival appears almost paradoxical. As this article has shown, however, applying the lessons of history and taking a balanced view of the present reveals patterns of continuity regarding states and their sovereignty which may trump the forces of change. Despite the enduring allure of narratives of statehood based on alternative identities, whether Arab or Islamic, these have not succeeded in opening up new pathways. ${ }^{58}$

Rather than imminent state failure, or state reconfiguration and border re-drawing what deserves attention is the domestic situation in the region and how the domestic frame is intimately connected with the issues under discussion here. Middle Eastern states are not 'strong' in the sense of enjoying popular legitimacy. Before the uprisings started, Eva Bellin spoke of the options for the region as more authoritarianism or more chaos - both of which are present today. ${ }^{59}$ However, Middle Eastern peoples, better informed and more connected than ever before, ${ }^{60}$ have strong views on the improvement of their condition as regular pre-and post-Arab Spring polling showed, even though there is no clear consensus on what the desired political arrangements should be. In the longer run, and drawing on the early phases of the uprisings, there is a third, more positive scenario: a gradual recalibration of popular sovereignty or democracy on Middle Eastern terms. The Arab Spring 'élan' involved public mobilisation

\footnotetext{
${ }^{57}$ Arial Ahram and Ellen Lust, 'The Decline and Fall of the Arab State', Survival 58:2, 2016: 7-34

58 Ewan Stein, 'Beyond Arabism vs. sovereignty. Relocating ideas in the international relations of the Middle East', Review of International Studies, 38/4 (2012): 881-905.

59 Bellin, Authoritarianism, p. 153.

60 Philip Seib, The Al Jazeera Effect (2008)
} 
and organization, not necessarily in any conventional democratic sense but one in which the popular demand for dignity and freedom represented a resounding rejection of authoritarianism. ${ }^{61}$ There is still considerable appetite for political change, which remains unsatisfied, but incremental moves to further realize the goals of reformers that were captured in the slogans of freedom and dignity in the early Arab Spring will continue. In this sense the revolutions are indeed unfinished...

If the current series of upheavals helped to affirm a 'sense of affinity and empathy among Arab publics' they have also affirmed the 'validity of state borders and existing sovereignties that divide the Arab world politically'. ${ }^{62}$ Despite contrary claims from media pundits and (mostly) Western analysts, there is little appetite today for a major rethinking of the principles of states, borders and sovereignty in the Middle East, whether from the perspective of major outsiders or insiders, although the rhetoric of change is a powerful tool. The Saudis don't want it; nor do the Iranians, Turks, or Israelis - the four major regional powers. Their positions all depend on the upholding of some kind of overarching territorial status quo. The United States and its European allies would like to see some reconstitution of the current system even if they broadly support a softening of its political arrangements. Russia, China and other 'emerging powers' with interests in the region do not advocate any major disturbance of the current territorial arrangements from which they too have benefitted in terms of oil and other economic contracts. The likely (and actual) scenario is a period of prolonged instability in which some states will continue to suffer from intense civil conflict - conflict that will spill over and blur borders while states and regimes will remain tenacious in their hold on territory power. We return then to Rotberg's state reconstruction scenario to consider how states might be reconstituted or return to differing degrees of health. ${ }^{63}$ With the shrinking of Da'esh-claimed territory, and the likely reconsolidation of Assad's authority in most of Syria, this is an ever more likely scenario.

\footnotetext{
${ }^{61}$ Larbi Sadiki 'Unruliness through Space and Time: Reconstructing 'Peoplehood' in the Arab Spring', in Larbi Sadiki (ed), The Routledge Handbook of the Arab Spring (London: Routledge, 2015): 1-5. ${ }^{62}$ Ayoob, Middle East: 3.

63 Rotberg, 'Failed States': 135.
} 
This perspective remains open to challenge and other contributors rightly point to the still fragile state of existing borders and the potential for longstanding changes. Indeed, micro-level studies of border issues alongside continuing sectarian fractures highlight the possibilities of reordering and resistance to a return to the status quo. Whatever the territorial arrangements look like by 2020 - and this article has argued for continuity over change - big questions will remain about the future of regional governance. Those who have offered plausible arguments about authoritarian survival in the Middle East, ${ }^{64}$ would agree that we are unlikely just to return to politics as before; that the issues that the present situation has given rise to are fraught with hazard and uncertainty, but also, and taking a longer term perspective, present a real opportunity for meaningful political change.

It will take time. State (re)building, like democratization, is usually messy, protracted and non-linear. ${ }^{65}$ Any more stable regional outcome may appear distant today, but it is an outcome that will be determined principally by the agency of regional, and above all, domestic actors, among whom some new alignments are already emerging and, only to a lesser extent, the interests and will of external actors to shape events - a will that, both positively and negatively, has been present since the late Ottoman period, but which at the moment, in a post-Iraq, post-crisis and quasi-Cold War environment, is in limited supply. But states and their borders, albeit contested, are here to stay.

64 Oliver Schlumberger, Debating Arab Authoritarianism, (Stanford, Stanford University Press, 2008); Larbi Sadiki, Rethinking Arab Democratization: Elections without Democracy, (Oxford, Oxford University Press, 2009).

65 Giovanni Capoccia and Robert Ziblatt 'The Historical Turn in Democratization Studies, Journal of Comparative Politics, 43: 8/9 (2010). 